\title{
PERANAN BIAYA SOSIAL DALAM MENINGKATKAN KINERJA SOSIAL DAN KEUANGAN PERUSAHAAN HIGH DAN LOW PROFILE
}

\author{
Henny Hendarti ${ }^{1}$
}

\begin{abstract}
Corporate social report had been done on company annual report in Indonesia. Workers theme was the most interesting theme amongs others. The condition happened consistently on high-profile dan low-profile industrial groups. But, corporate social report in Indonesia was still low. It was assumed because the company did not taking advantage to the annual report as a communication media between company and stakeholders. Possibly, it was because the company only used annual report as a report for the stakeholders and debt holders or as information for future investors. Another factor causing the low number was because the company was only done small social activities.
\end{abstract}

Keywords: social cost, social performances, financial performances

ABSTRAK
Pengungkapan sosial telah dilakukan pada laporan tahunan perusahaan di
Indonesia. Tema ketenagakerjaan paling banyak mendapat perhatian diantara tema
pengungkapan sosial. Kondisi itu konsisten pada kelompok industri high-profile dan low-
profile. Akan tetapi, pengungkapan sosial di Indonesia relatif masih rendah. Diduga
perusahaan tidak memanfaatkan laporan tahunan sebagai media komunikasi antara
perusahaan dan stakeholders. Kemungkinan, perusahaannya hanya memanfaat laporan
tahunan sebagai laporan kepada stakeholders dan debthholders atau sebagai informasi
bagi calon investor. Faktor lain yang menyebabkan rendahnya angka tersebut, diduga
perusahaan memang hanya melakukan sedikit aktivitas sosial.
Kata kunci: biaya sosial, kinerja sosial, kinerja keuangan

${ }^{1}$ Staf Pengajar Fakultas Ekonomi Jurusan Manajemen, UBiNus, Jakarta 


\section{PENDAHULUAN}

Laporan tahunan merupakan media utama penyampaian informasi oleh manajemen kepada pihak di luar perusahaan. Informasi yang diungkap dalam laporan tahunan dapat dikelompokkan menjadi pengungkapan wajib (mandatory disclosure) dan pengungkapan sukarela (voluntary disclosure). Pengungkapan wajib merupakan informasi dalam laporan tahunan di Indonesia dikeluarkan oleh pemerintah, yaitu melalui Keputusan Ketua Bapepam No. Kap-17/PM/1995 yang selanjutnya diubah melalui Keputusan Ketua Bapepam No. Kep-38/PM/1996. Peraturan yang lama berlaku bagi semua perusahaan yang telah melakukan penawaran umum dan perusahaan publik.

Sebagai bagian tak terpisahkankan dari perusahaan, akuntansi berupaya mengakomodasikan perubahan kecenderungan tersebut dengan melahirkan sub-disiplin akuntasi sosial. Terdapat pergeseran mendasar yang dilakukan disiplin akuntansi melalui wacana ini, yaitu perubahan paradigma pertanggungjawaban. Bila selama ini produk akuntansi dimaksudkan sebagai pertanggungjawaban manajemen kepada pemilik saham, kini paradigma tersebut diperkuas menjadi pertanggungjawaban kepada seluruh stakeholders. Standar akuntansi keuangan yang dikeluarkan oleh Ikatan Akuntan Indonesia (IAI), secara implicit telah mengakomodasikan hal tersebut. Misalnya, sebagaimana tertulis dalam Pernyataan Standar Akuntansi Keuangan (PSAK) No. 1 (Revisi 1998) paragraph kesembilan: Perusahan dapat pula menyajikan laporan tambahan, seperti laporan mengenai lingkungan hidup dan laporan nilai tambah (value added statement), khususnya bagi industri tempat faktor lingkungan hidup memegang peranan penting dan bagi industri yang menganggap pegawai sebagai kelompok pengguna laporan yang memegang peranan penting.

Gray et. al. (1998b:50-56) merangkum berbagai teori yang dipergunakan oleh para peneliti untuk menjelaskan kecenderungan pengungkapan sosial dalam tiga kelompok utama. Pertama, Decision-Usefulness Studies. Sebagian studi yang dilakukan oleh para peneliti yang mengemukakan teori ini menemukan bukti bahwa informasi sosial dibutuhkan oleh para users. Para analis, banker, dan pihak lain yang dilibatkan dalam penelitian tersebut diminta melakukan pemeringkatan terhadap infoemasi akuntansi. Informasi akuntansi tersebut tidak terbatas pada informasi akuntansi tradisional yang telah dikenal selama ini, namum juga informasi yang lain yang relatif baru dalam wacana akuntansi. Mereka menempatkan informasi aktivitas sosial perushaan pada psosisi yang "moderately important."

Kedua, Economic Theory Studies. Studi tentang teori ekonomi dalam corporate responsibility reporting ini mendasarkan diri pada economic egency theory dan accounting positive theory. Penggunaan agency theory menganalogikan manajemen adalah agen dari satu prinsipal. Lazimnya, prinsipal diartikan sebagai saham atau traditional users lain. Namun, pengertian prisnsipal tersebut meluas menjadi seluruh interest group perusahaan yang bersangkutan. Sebagai agen, manajemen akan berupaya 
mengoperasikan perusahaan sesuai dengan keinginan publik (baca: stakeholder). Ketiga, Social and Political Theory Studies. Studi di bidang ini menggunakan teori stakeholders, teori legitimasi organisasi, dan teori ekonomi politik. Teori Stakeholder mengasumsikan bahwa eksistensi perusahaan ditentukan oleh para stakeholders. Perusahaan berusaha mencari pembenaran dari para stakeholder dalam menjalankan operasi perusahaannya. Semakin kuat posisi stakeholders, semakin besar pula kecenderungan perusahaan mengadaptasi diri terhadap keinginan para stakeholders-nya.

Para peneliti akuntansi sosial tertarik untuk menguji pengungkapan sosial pada berbagai perushaan yang memiliki perbedaan karakteristik. Salah satu perbedaan karakteristik yang menjadi perhatian adalag tipe industri, yaitu industri yang high-profile dan industri low-profile. Untuk membedakan kedua jenis industri tersebut, definisi yang diusulkan oleh Robert (dalam Hackston and Milne, 1996:87) dapat dipergunakan. Robert mendefinisikan high-profile companies sebagai perusahaan yang memilik consumer visibility, tingkat risiko politik dan tingkat kompetisi yang tinggi.

David Ricardo mengembangkan perangkat teori yang menyangkut empat kelompok, permasalahannya, yaitu teori tentang nilai dan harga barang; Teori tentang distribusi pendapatan sebagai pembagian hasil dari seluruh produksi dan disajikan sebagai teori upah, teori sewa tanah, teori bunga dan laba; Teori tentang perdagangan internasional; Teori tentang akumulasi dan perkembangan ekonomi (Sumitro Djojohadikusumo, 1991:31). Pada dasarnya, pemikir ekonomi tersebut berpendapat bahwa aktivitas ekonomi harus memberikan kontribusi kepada masyarakat secara menyeluruh, yaitu keserasian dalam kehidupan ekonomi dan kesejahteraan umum.

Sejalan dengan perkembangan aktivitas ekonomi yang dilandasi oleh pemikir ekonomi mahzab klasik, akuntansi pun mengalami sejarah perkembangan yang panjang. Perkembangan sejarah akuntansi tidak lepas dari praktik pencatatan akuntansi. Pada hakikatnya, para ahli sepakat apabila dikatakan bahwa praktik akuntansi dalam arti pencatatan kejadian bisnis sudah lama dimulai, yaitu sejak adanya aktivitas ekonomi. Pada dekade tahun 1975 akuntansi sosial menjadi isu baru yang membahas pencatatan setiap transaksi keuangan perusahaan yang mempengaruhi lingkungan masyarakat. Apabila perusahaan tidak memperhatikan seluruh faktor yang mengelilinginya mulai dari karyawan, konsumen, lingkungan, dan sumber daya alam dalam satu kesatuan yang saling mendukung sebagai suatu sistem, maka akhirnya kan mengakhiri eksistensi perusahaan itu sendiri (Marbun, 1991). Biaya yang berkaitan dengan kemasyarakatan tersebut disebut biaya sosial.

Biaya sosial yang harus dikeluarkan oleh perusahaan dalam perkembangannya sampai saat ini masih atas dasar desakan masyarakat. Walupun masyarakat menuntut perusahaan untuk menghasilkan produk sebagai kebutuhannya tetapi sekarang masyarakat menuntut agar perusahaan bertanggung jawab terhadap masyarakat melalui kepedulian terhadap masalah sosial. Artinya, hak dan kewajiban perusahaan sama seperti 
layaknya penduduk sebagai bagian dari masyarakat yang diharapkan menjadi penduduk yang memiliki tanggung jawab sosial bukan perusak.

Kepedulian perusahaan terhadap masyarakat harus diungkapkan berupa laporan tanggung jawab sosial yang ternyata dapat berdampak terhadap kemajuan perusahaan itu sendiri. Laporan tanggung jawab sosial perusahaan, bukan hanya bermanfaat bagi masyarakat yang ada di luar perusahaan tetapi para pegawai pun sangat memperhatikan mengenai masalah ini, sebagai bahan informasi mengenai tanggung jawab perusahaan terhadap masyarakat. Hal itu karena laporan tanggung jawab sosial perusahaan dapat memberikan semangat untuk berprestasi dalam melaksanakan tugasnya.

Para investor juga menaruh perhatian terhadap isu lingkungan ini, terutama kaitannya dengan pemilihan investasi, tentunya para investor memilih investasi yang paling menguntungkan. Namun, Kepedulian sosial perusahaan ini masih dipengaruhi skala usaha dan kelompok perusahaan tertentu saja (Cowen at al., 1987). Bahkan dalam perkembangan selanjutnya bahwa pihak yang berkepentingan menaruh perhatian terhadap pengungkapan biaya sosial ini, terutama dalam keutusan ekonominya (McGuire et al., 1988). Bahkan, R.W Robert berpendapat bahwa pengungkapan tanggung jawab sosial ini harus digunakan sebagai salah satu strategi dalam mengembangkan usahanya (R.W Robert, 1992). Para peneliti sebelumnya berpendapat bahwa biaya sosial yang dikeluarkan perusahaan lebih mengarah kepada citra positif dari masyarakat terhadap perusahaan,karena perusahaan sudah memiliki kepedulian terhadap masyarakat. Namun para peneliti berikutnya, biaya sosial yang dikeluarkan perusahaan berpengaruh pula terhadap kinerja keuangan. Bahkan Anderson \& Frankle berpendapat lebih jauh lagi, implikasi dari laba perusahaan akan berpengaruh terhadap naik turunnya harga saham di bursa bagi perusahaan yang memiliki kepedulian sosial yang tinggi (Anderson \& Frankle, 1980).

Salah satu cara untuk mengukur luas pengungkapan yang digunakan dalam penelitian sebelumnya adalah berdasarkan daftar item pengungkapan yang dimuat dan/atau dapat dimuat dalam laporan tahunan. Pengukuran luas pengungkapan dengan cara tersebut ada dua macam, yaitu memberi bobot kepada setiap item dan tanpa memberi bobot kepada setiap item.

\section{PEMBAHASAN}




\section{Profil Sampel}

Bila dilihat dari ukuran perusahaan (dinilai dari nilai aktiva), sampel yang terpilih memiliki keragaman. Keragaman ukuran perusahaan yang menjadi sampel terlihat pada Tabel 1 (dari hasil penelitian yang dilakukan oleh Muhammad Muslim Utomo, SE, Akt., Yayasan Mitra Mandiri Pekalongan).

Tabel 1 Komposisi Sampel Berdasarkan Ukuran Perusahaan ((Miliar rupiah)

\begin{tabular}{ccccccc}
\hline Nilai Aktiva & \multicolumn{2}{c}{ High-profile } & \multicolumn{2}{c}{ Low-profile } & \multicolumn{2}{c}{ Total } \\
& $\sum$ & $\%$ & $\sum$ & $\%$ & $\sum$ & $\%$ \\
$\geq 5.000$ & 4 & 4,94 & 4 & 4,94 & 8 & 9,88 \\
$4.000-4.999$ & 2 & 2,47 & 1 & 1,23 & 3 & 3,70 \\
$3.000-3.999$ & 3 & 3,70 & 4 & 4,94 & 7 & 8,64 \\
$2.000-2.999$ & 9 & 11,11 & 2 & 2,47 & 11 & 13,58 \\
$1.000-1.999$ & 1 & 1,23 & 7 & 8,64 & 8 & 9,88 \\
$500-999$ & 3 & 3,70 & 7 & 8,64 & 10 & 12,35 \\
$<500$ & 17 & 20,99 & 17 & 20,99 & 34 & 41,98 \\
\hline Jumlah & $\mathbf{3 9}$ & $\mathbf{4 8 , 1 5}$ & $\mathbf{4 2}$ & $\mathbf{5 1 , 8 5}$ & $\mathbf{8 1}$ & $\mathbf{1 0 0}$ \\
\hline
\end{tabular}

Sumber: data diperoleh dari perusahaan neraca sampel, diolah.

Keterangan:

$\Sigma=$ jumlah perusahaan sample

$\%=$ Persentase perusahaan pada kelas tersebut terhadap total perusahaan sample

Nilai aktiva yang diperoleh dari neraca tahun 1998

Sampel yang memiliki kekayaan terbesar adalah PT Indah Kiat Paper \& Pulp Corporation Tbk (perusahaan high-profile), dengan nilai aktiva terbesar Rp59.759,752 miliar. Sampel dengan nilai aktiva terkecil adalah PT Sofyan Hotels Tbk (perusahaan high-profile) dengan asets sebesar Rp11,797 miliar.

\section{Pemetaan Pengungkapan Sosial}

Pada bagian ini, peneliti akan memetakan pengungkapan sosial yang dilakukan oleh perusahaan di Indonesia, baik industri high-profile maupun industri low-profile. Pada tabel 2a, 2b, 3a, dan 3b, cells yang berada di sebelah kanan item pengungkapan sosial menunjukkan persentase perusahaan yang melakukan pengungkapan sosial yang sesuai dengan kriteria cell tersebut. Kriteria cell merupakan perpaduan antara baris dan kolom.

Tabel 2a Persentase Perusahaan High-profile yang Melakukan Pengungkapan Sosial Berdasarkan Tema dan Lokasi di Dalam Laporan Tahunan

(dalam \%) 


\begin{tabular}{lcccccc}
\hline \multirow{2}{*}{ TEMA } & \multicolumn{5}{c}{ LOKASI DI DALAM LAPORAN TAHUNAN } \\
\cline { 2 - 7 } PENGUNGKAPAN & Overview & S.Koms. & S.Dir & Feature & Cat. L.L. & DAM \\
\hline Kemasyarakatan & 2,56 & 2,56 & 12,82 & 15,39 & 48,72 & 7,69 \\
Produk dan Konsumen & 20,51 & 17,95 & 41,01 & 15.36 & 2,56 & 20,51 \\
Ketenagakerjaan & 15,39 & 56,41 & 74,36 & 30.77 & 89,74 & 20,51 \\
\hline
\end{tabular}

Keterangan: S.Koms= Surat dari dewan komisaris; S.Dir= Surat dari dewan direksi; Cat $\mathrm{LK}=$ Catatan atas laporan keuangan; DAM= Diskusi dan Analisis Manajemen

Tabel 2a menunjukkan proporsi (persentase) perusahaan dalam industri highprofile yang melakukan pengungkapan sosial berdasarkan tema dan lokasi pengungkapan. Tema ketenagakerjaan merupakan tema yang diungkap oleh banyak perusahaan: $89,74 \%$ perusahaan mengungkapnya di bagian "Catatan atas laporan keuangan"; 74,36\% mengungkapnya di bagian "Surat dari dewan direksi". Bila dilihat dari lokasi laporan tahunan, banyak perusahaan yang memanfaatkan bagian "Surat dari dewan direksi" untuk melakukan pengungkapan sosialnya, Sebanyak 12,82\% (kemasyarakatan); 41,01\% (produk dan konsumen) dan 74,36\% (ketenagakerjaan) dari perusahaan sub sampel higprofile melakukan pengungkapan sosial di bagian ini. Kondisi yang hampir serupa terjadi pada perusahaan sub-sampel low-profile (lihat Tabel 3b).

Tabel 2b Persentase Perusahaan Low-profile yang Melakukan Pengungkapan Sosial Berdasarkan Tema dan Lokasi dalam Laporan Tahunan (dalam \%)

\begin{tabular}{lcccccc}
\hline TEMA & \multicolumn{5}{c}{ LOKASI DI DALAM LAPORAN TAHUNAN } \\
\cline { 2 - 6 } PENGUNGKAPAN & Overview & S.Koms. & S.Dir & Feature & Cat. L.L. DAM \\
\hline Kemasyarakatan & 4,76 & 2,38 & 9,52 & 4,76 & 42,86 & 11,90 \\
Produk dan Konsumen & 16.67 & 4,76 & 23,81 & 11,90 & 0 & 9,52 \\
Ketenagakerjaan & 9.52 & 38,10 & 59,52 & 14,29 & 90,48 & 19,05 \\
\hline
\end{tabular}

Keterangan: S.Koms= Surat dari dewan komisaris; S.Dir= Surat dari dewan direksi; Cat $\mathrm{LK}=$ Catatan atas laporan keuangan; DAM= Diskusi dan Analsiis Manajemen

Serupa dengan perusahaan high-profile, tema ketenagakerjaan juga diungkap oleh banyak perusahaan. Sekitar $90 \%$ perusahaan low-profile melakukan pengungkapan tema ini pada bagian "Catatan atas laporan keuangan" dan 59,52\% pada bagian "Surat dari dewan direksi". Banyaknya perusahaan yang melakukan pengungkapan tema ketenagakerjaan karena ada tiga item dalam tema ini yang diungkap oleh hampir setiap perusahaan, baik low-profile maupun high-profile, yaitu pendidikan dan latihan, gaji dan tunjangan, dan kesejahteraan lain.

Tabel 3a Persentase Perusahaan High-profile yang melakukan Pengungkapan sosial Berdasarkan Tema dan Tipe Pengungkapan (dalam \%) 


\begin{tabular}{lccc}
\hline TEMA & \multicolumn{2}{c}{ LOKASI DI DALAM LAPORAN TAHUNAN } \\
\cline { 2 - 4 } & Naratif Kualitatif & $\begin{array}{c}\text { Kuantitatif } \\
\text { Moneter }\end{array}$ & $\begin{array}{c}\text { Non-Kuantitati } \\
\text { Moneter }\end{array}$ \\
\hline Kemasyarakatan & 30,77 & 12,82 & 46,15 \\
Produk dan Konsumen & 66,67 & 40,26 & 10,26 \\
Ketenagakerjaan & 87,18 & 56,41 & 94,87 \\
\hline
\end{tabular}

Sebesar $94,87 \%$ perusahaan high-profile melakukan pengungkapan tema ketenagakerjaan dengan tipe pengungkapan kuantitatif moneter dan 87,18\% dalam bentuk naratif kualitatif. Tingginya persentase itu disebabkan item gaji, item tunjangan dan kesejahteraan lain, dan item pendidikan dan latihan pada tema ketenagakerjaan sering kali dinyatakan dalan dua bentuk, yaitu kuatitatif moneter dan naratif kualitatif. Tema lain yang menjadi concern perusahaan high-profile adalah produk dan konsumen. Sebanyak $66,67 \%$ perusahaan high-profile mengungkap tema ini secara naratf kualitatif. Umumnya, perusahaan tersebut mengungkap item "Mutu produk" dan "Penghargaan kualitas" pada laporan tahunan mereka secara naratif kualitatif.

Tabel 3b Persentase Perusahaan Low-profile yang melakukan Pengungkapan sosial Berdasarkan Tema dan Tipe Pengungkapan (dalam \%)

\begin{tabular}{lccc}
\hline TEMA & \multicolumn{3}{c}{ LOKASI DI DALAM LAPORAN TAHUNAN } \\
\cline { 2 - 4 } PENGUNGKAPAN & $\begin{array}{l}\text { Naratif } \\
\text { Kualitatif }\end{array}$ & $\begin{array}{l}\text { Kuantitatif } \\
\text { Moneter }\end{array}$ & $\begin{array}{l}\text { Kuantitati } \\
\text { Moneter }\end{array}$ \\
\hline Kemasyarakatan & 23,81 & 2,38 & 52,38 \\
Produk dan Konsumen & 42,86 & 2,38 & 0 \\
Ketenagakerjaan & 85,71 & 45,24 & 90,48 \\
\hline
\end{tabular}

Serupa dengan perusahaan di industri high-profile, perusahaan low-profile juga banyak melakukan pengungkapan tema ketenagakerjaan. Pengungkapan tersebut berbentuk kuantitatif moneter $(90,48 \%)$, naratif kualitatif $(85,47 \%)$, dan dalam bentuk kuantitatif nonmoneter (45,24\%). Sebaliknya, tidak ada perusahaan low-profile yang melakukan pengungkapan pada tema pokok produk dan konsumen dalam bentuk kuantitatif moneter.

\section{Hasil Uji Beda Pengungkapan Sosial pada Dua Tipe Industri}

Hipotesis yang menyatakan bahwa aktivitas pengungkapan sosial yang dilakukan oleh perusahaan-perusahaan dalam industri low-profile, akan diperlihatkan pada tabel 4 . Selanjutnya, hasil pengujian statistik $\mathrm{Z}$ akan diperlihatkan pada tabel 5.

Tabel 4 Rerata dan Persentase Pengungkapan Sosial pada Seluruh Tema 


\begin{tabular}{clccc}
\hline \multicolumn{1}{c}{ Tipe Industri } & \multicolumn{1}{c}{ Proksi } & Rerata & $\sum$ Item & \% dari $\sum$ Item \\
High-profile & Kemasyarakatan & 1,462 & 10 & 14,62 \\
& Produk \& Konsumen & 1,359 & 5 & 27,18 \\
& Ketenagakerjaan & 4,821 & 15 & 32,14 \\
& Total & $\mathbf{7 , 6 4 1}$ & $\mathbf{3 0}$ & $\mathbf{2 5 , 4 7}$ \\
Low-profile & Kemasyarakatan & 1,190 & 10 & 11,90 \\
& Produk \& Konsumen & 0,738 & 5 & 14,76 \\
& Ketenagakerjaan & 4,167 & 15 & 27,78 \\
& Total & $\mathbf{6 , 0 9 5}$ & $\mathbf{3 0}$ & $\mathbf{2 0 , 3 2}$ \\
\multirow{5}{*}{ Total } & & & & \\
& Kemasyarakatan & 1,321 & 10 & 13,21 \\
& Produk \& Konsumen & 1,037 & 5 & 20,74 \\
& Ketenagakerjaan & 4,481 & 15 & 29,87 \\
& Total & $\mathbf{6 , 8 4 0}$ & $\mathbf{3 0}$ & $\mathbf{2 2 , 8 0}$ \\
\hline
\end{tabular}

Rerata pada Tabel 4 menunjukkan bahwa pengungkapan sosial yang dilakukan oleh perusahaan dalam industri high profile lebih tinggi daripada pengungkapan sosial yang dilakukan oleh perusahaan dalam industri low-profile $(7,641: 6,095)$. Hasil yang sama ditunjukkan oleh rerata pada tiap proksi. Penjelasan yang dapat dikemukakan dalam perusahaan high-profile memiliki sensitivitas lingkungan sosial yang lebih tinggi daripada perusahaan low-profile. Perusahaan high-profile umumnya memiliki sifat: memiliki tenaga kerja yang besar, ukuran perusahaan yang lebih besar, serta konsumen lebih berhati-hati terhadap produk dan layanan perusahaan high-profile.

Tabel 4 menunjukkan tema yang paling banyak diungkapkan adalah tema ketenagakerjaan: 4,481 item. Secara persentatif, angka tersebut merupakan 29,87\% dari total item pada tema tersebut yang harus diungkap. Hasil itu serupa dengan tema Andrew et.al. (1989: 373) ketika meneliti pengungkapan sosial di negara berkembang (Malaysia dan Singapura). Mereka mendapati angka $71 \%$ dari total pengungkapan sosial yang dilakukan oleh perusahaan tersebut merupakan pengungkapan dalam tema human resources. Andrew et.al. (1989: 373) menduga kecenderungan tersebut disebabkan besarnya perhatian pemerintah setempat pda tema tersebut. Bila dilihat dari tipe industri, tema ketenagakerjaan juga menempati urutan teratas dalam hal proporsi item yang paling banyak diungkap, baik pada industri high-profile maupun pada industri low-profile. Pada industri high-profile, item yang diungkap pada tema ini mencapai 4,821 item atau 32,14\% dari seluruh item yang harus diungkap pada tema ini (15 item) sedangkan pada industri low-profile, terdapat 4,167 item atau $27,78 \%$ dari seluruh item pada tema ini.

Bila tema pengungkapan diranking berdasarkan urutan proporsi pengungkapan maka susunan yang diperoleh adalah tema ketenagakerjaan, tema kemasyarakatan, dan tema produk dan konsumen. Bila dikaitkan dengan teori legitimasi, teori agensi, atau teori stakeholders, urutan tesebut juga mencerminkan urutan tuntutan publik terhadap perusahaan. Tuntutan dibidang ketenagakerjaan relatif lebih menonjol daripada tuntutan dibidang lain. Tuntutan dibidang ketenagakerjaan umumnya berkaitan dengan 
ketidakmampuan perusahaan dalam memenuhi kebutuhan kesejahteraan karyawan, misalnya kecilnya tingkat upah dan keengganan manajemen banyak perusahan dalam memenuhi tunjangan hari raya (THR).

Tabel 4 juga memperlihatkan sosial yang dilakukan oleh perusahaan masih relatif sangat sedikit. Persentase tertinggi yang dicapai tema ketenagakerjaan, hanya sekitar $30 \%$ (total 29,87\%; high-profile 32,14\%; dan low-profile 27,78\%) dari daftar pengungkapan sosial yang seharusnya mereka ungkap. Secara keseluruhan, pengungkapan sosial perusahaan di Indonesia hanya mencapai angka 22,80\% (high-profile 25,47\%; dan lowprofile 20,32\%). Ada beberapa kemungkinan yang menyebabkan sedikitnya pengungkapan sosial yang dilakukan oleh perusahaan tersebut, antara lain: \{erusahaan telah melakukan pengungkapan pada periode sebelumnya sehingga merasa tidak perlu mengungkapnya lagi; Perusahaan tidak merasa perlu melakukan pengungkapan pada item tertentu karena menganggap hal yang biasa. Misalnya, perusahaan tidak mengungkapkan donasi ke lembaga keagamaan atau sponsorship kegiatan kampus karena menganggap informasi tersebut sesuatu yang wajar dan nilainya tidak signifikan sehingga tidak perlu diungkap; Laporan tahunan didesain untuk kepentingan shareholders sehingga informasi yang dibutuhkan oleh stakeholders lain tidak diungkap dalam laporan tahunan. Perusahaan memilih media lain untuk pengungkapan selain kepada pemegang saham.

Bila ketiga kemungkinan tersebut benar, terdapat kesenjangan antara aktivitas sosial dan pengungkapan sosial dalam laporan tahunan. Artinya, perusahaan sebelum sepenuhnya memanfaatkan laporan tahunan sebagai sarana komunikasi antara phak manajemen dengan para stakeholders di luar pemegang saham. Perusahaan masih memandang laporan tahunan hanya diperuntukkan kepada pemegang saham, debtholders, dan calon investor. Selain tiga kemungkinan tersebut, rendahnya tingkat pengungkapan juga dimungkinkan terjadi karena faktor kepedulian sosial yang dimiliki oleh perusahaan memang yang masih rendah.

Tabel 5 Nilai Z dab Signifikan Antara High-profile dan Low-profile

\begin{tabular}{ccccc}
\hline \multicolumn{1}{c}{ Proksi } & $\mathbf{Z}$ & Keputusan pada H0 & P & Signifikansi \\
\hline Kemasyarakatan & 0,707 & Diterima & 0,24 & Tidak signifikan \\
Produk \& Konsumen & 2,472 & Ditolak & 0,01 & Sangat signifikan \\
Ketenagakerjaan & 1,497 & Diterima & 0,07 & Tidak signifikan \\
\hline \multicolumn{1}{c}{ Total } & $\mathbf{2 , 1 7 1}$ & Ditolak & $\mathbf{0 , 0 1}$ & Sangat signifikan \\
\hline
\end{tabular}

Tabel 5 menunjukkan nilai $Z_{\text {hitung }}$ untuk total pengungkapan sebesar 2,253. Angka itu lebih besar daripada nilai $Z_{\text {tabel }}(1,645)$ sehingga berada di daerah penolakan $H_{0}$. Artinya, hipotesis alternatif yang diajukan diterima pada proksi produk dan konsumen. Nilai probabilitas pada tema produk dan konsumen menunjukkan hasil yang sangat signifikan $(\mathrm{p}=0,01)$ sedangkan, $Z_{\text {hitung }}$ untuk tema kemasyarakatan menunjukkan angka 0,707 yang berarti berada di daerah penerimaan $\mathrm{H}_{0}$. Kondisi serupa dialami oleh tema ketenagakerjaan yang memperoleh $Z_{\text {hitung }}=1,497$. Artinya, tidak ada perbedaan 
pengungkapan sosial antara industri high-profile dan low-profile. Artinya, concern perusahaan di Indonesia terhadap tema kemasyarakatan dan tema ketenagakerjaan tidak dipengaruhi oleh perbedaan tipe industri.

\section{Gambaran Cara Pengungkapan Tanggung Jawab Sosial Perusahaan}

Cara pengungkapan tanggung jawab sosial perusahaan, khususnya perusahaan terbuka di Indonesia menggunakan media yang berbeda-beda. Kelompok biaya sosial dan media pengungkapan yang paling banyak dipilih oleh perusahaan adalah penyajian biaya pengelolaan lingkungan dalam prospektus $21.0 \%$, biaya kesejahteraan pegawai yang disajikan dalam catatan atas laporan keuangan $36.1 \%$, biaya untuk masyarakat di sekitar perusahaan yang disajikan didalam laporan tahunan $15.0 \%$, dan biaya pemantau prosuk yang disajikan didalam catatan atas laporan keuangan, ada 3.8\%.

Bervariasinya cara memilih media pengungkapan tanggung jawab sosial perusahaan, nampaknya didasarkan kepada kelaziman dan untuk kepentingan tertentu, seperti pengungkapan biaya pengelolaan lingkungan lebih banyak perusahaan yang memilih media laporan prospektus karena laporan prospektus itu dapat digunakan sebagai ajang propaganda pada saat perusahaan menjual saham perdananya di bursa efek. Pengungkapan tersebut minimal memberikan kesan bahwa perusahaan sudah memiliki kepedulian dalam pengelolaan lingkungan. Diharapkan dengan adanya pengungkapan tersebut dapat menarik para calon investor agar tertarik untuk membeli saham perusahaan. Pengungkapan tanggung jawab sosial perusahaan mengenai kesejahteraan pegawai, masyarakat di luar perusahaan, dan biaya pemantauan produksi pada umumnya memilih media pengungkapan melalui laporan tahunan dan catatan atas laporan keuangan. Hal itu didasarkan pada kelaziman yang dilakukan pada perusahaan pada umumnya di Indonesia.

Penyebab lain yang mengakibatkan ketidakseragaman cara pengungkapan tanggung jawab sosial perusahaan tersebut karena belum adanya aturan yang jelas mengenai cara penyajiannya maupun komponen yang termasuk biaya sosial tersebut. Akibatnya, masing-masing perusahaan mempunyai cara dan kebijakan masing-masing mengenai pengeluaran yang menyangkut biaya sosial itu. Hasil penelitian ini sesuai pula dengan penelitiannya Yamagami dan Kokubu (1991) pada Tabel 6 berikut ini.

Tabel 6 Pengungkapan Tanggung Jawab Sosial Perusahaan di Jepang

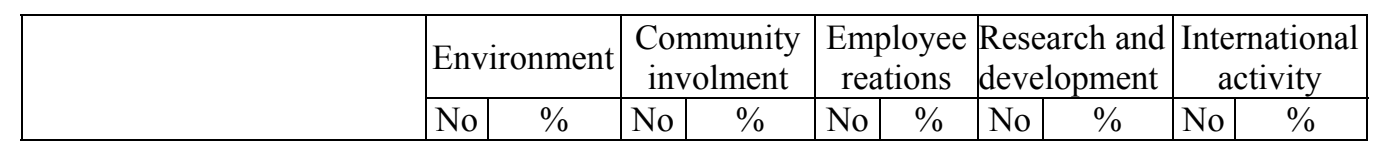




\begin{tabular}{|l|c|c|c|c|c|c|c|c|c|c|}
\hline $\begin{array}{l}\text { Operating report } \\
\text { (total: } 49 \text { companies) } \\
\begin{array}{l}\text { English version report } \\
\text { (total: } 47 \text { companies) }\end{array}\end{array}$ & 0 & 0 & 6 & 12.2 & 21 & 42.9 & 38 & 77.6 & 23 & 46.9 \\
$\begin{array}{l}\text { Public relations report } \\
\text { (total:49 companies) } \\
\begin{array}{l}\text { Average percentage of the } \\
\text { three report }\end{array}\end{array}$ & 13 & 26.5 & 25 & 51.0 & 17 & 34.7 & 41 & 83.7 & 39 & 79.6 \\
\hline
\end{tabular}

Sumber: Yamagami dan Kokubu (1991)

Berdasarkan hasil penelitian Yamagami dan Kokubu (1991) pada Tabel 6, pengungkapan tanggung jawab sosial, biaya sosial dikelompokan berdasarkan lingkungan (termasuk didalamnya energi dan pengamanan produk), lingkungan masyarakat, kepegawaian, penelitian dan pengembangan, dan aktivitas international. Media yang digunakan adalah laporan operasional, laporan versi bahasa inggris, dan laporan untuk publik. Hasilnya adalah biaya lingkungan yang disajikan pada laporan operasional $0 \%$, pada laporan versi bahasa inggris $6.4 \%$, pada laporan untuk publik 26.5\%; Biaya lingkungan masyarakat disajikan pada laporan operasional $12.2 \%$, pada laporan versi bahasa inggris $19.1 \%$, pada laporan untuk publik 51.0\%; Biaya kepegawaian disajikan pada laporan oprasional $42.9 \%$, pada laopran versi bahasa inggris $25.5 \%$, pada laporan untuk publik $34.7 \%$. Hasil penelitian menyimpulkan bahwa pada umumnya media pengungkapan yang paling banyak digunakan adalah laporan untuk publik, terutama yang menyangkut lingkungan $26.5 \%$, lingkungan masyarakat $51.1 \%$, dan aktivitas intrnasional $79.6 \%$. Media laporan versi bahasa inggris lebih banyak mengungkapkan mengenai penelitian dan pengembangan $87.2 \%$, aktivitas international $74.5 \%$. Paling rendah adalah laporan operasional yang mengungkapkan mengenai kepegawaian $42.9 \%$.

\section{PENUTUP}

Pengungkapan sosial telah dilakukan pada laporan tahunan perusahaan di Indonesia. Tema ketenagakerjaan paling banyak mendapat perhatian diantara tema pengungkapan sosial. Kondisi itu konsisten pada kelompok industri high-profile dan lowprofile. Pengungkapan sosial di Indonesia relatif masih rendah. Diduga perusahaan tidak memanfaatkan laporan tahunan sebagai media komunikasi antara perusahaan dan stakeholders. Kemungkinan, perusahaannya hanya memanfaat laporan tahunan sebagai laporan kepada stakeholders dan debthholders atau sebagai informasi bagi calon investor. Faktor lain yang menyebabkan rendahnya angka tersebut, diduga perusahaan memang hanya melakukan sedikit aktivitas sosial. Statistik uji $Z$ yang digunakan untuk menguji hipotesis penelitian ini berhasil membuktikan bahwa pengungkapan sosial yang dilakukan oleh perusahaan dalam industri high-profile lebih tinggi daripada pengungkapan sosial yang dilakukan oleh perusahaan dalam industri low-profile. Ketika dilakukan pengujian partial, hasil serupa juga diperoleh pada tema produk dan konsumen. Penelitian ini gagal membuktikan hipotesis pada tema kemasyarakatan dan tema 
ketenagakerjaan. Pengujian statistik pada kedua tema tersebut menunjukkan hasil yang tidak signifikan.

\section{Pengaruh Biaya Pengelolaan Lingkungan Terhadap Kinerja Sosial Perusahaan}

Berdasarkan hasil penelitian perhitungan statistik pengaruh biaya pengelolaan lingkungan terhadap kinerja sosial menghasilkan koefisien diterminasi $\left(\mathrm{R}^{2}\right)$ sebesar 0.572. Hal itu menunjukan bahwa 57.2\% variasi dalam Y kinerja sosial dapat dijelaskan oleh $\mathrm{X}_{17}$ biaya gaji dan upah bagian lingkungan, sisanya sebesar $42.8 \%$ dijelaskan oleh variabel lain yang tidak dimasukan dalam model persamaan ini. Simpulan itu selanjutnya diuji secara parsial menggunakan uji $\mathrm{t}, \alpha=5 \%$ uji 2 arah menunjukan $t_{\text {hitung }} 4.905>$ $\mathrm{t}_{(0.05 ; 14)}$ tabel ,095. Kemudian secara serempak melalui uji $\mathrm{F}, \alpha=5 \%$. Hasil perhitungan $\mathrm{F}_{\text {hitung }}$ sebesar 24.056 dengan demikian $\mathrm{F}_{\text {hitung }}>\mathrm{F}_{\text {tabel }}$ (4.38) maka $\mathrm{H}_{0}$ ditolak. Artinya, variabel biaya gaji dan upah bagian lingkungan baik secara parsial maupun serempak berpengaruh secara nyata terhadap kinerja sosial perusahaan.

Hasil penelitian menggambarkan bahwa biaya pengelolaan lingkungan yang paling dominan berpengaruh terhadap kinerja sosial perusahaan terbuka di Indonesia adalah gaji dan upah untuk bagian lingkungan. Hal itu berarti semakin besar biaya gaji dan upah yang dikelaurkan untuk bagian lingkungan yang khusus menengani masalah lingkungan akan meningkatkan kinerja sosial perusahaan. Hal tersebut disebabkan, dengan adanya pegawai khusus yang beratensi terhadap lingkungan akan terhindar dari persoalan lingkungan sehingga akan berimpilasi trhadap membaiknya citra perusahaan. Hasil penelitian ini sesuai pula dengan hasil penelitian (Belkaoui \& Karpik, 1989); (Roberts, R.W., 1992); (Trotman \& Bradley, 1981, Cowen dkk., 1987; Roberts R.W., 1992). Di samping itu, sesuai pula dengan pendapat yang dikemukakan oelh Gibson dkk, mengenai kepuasaan kerja yang menyatakan bahwa kepuasan kerja berpangkal dari berbagai aspek kerja, seperti upah, kesempatan promosi, penyelia (supervisi), kebijakan dan prosedur, keanggotaan kelompok kerja, kondisi kerja, dan tunjangan (Gibson, 1992: $62)$.

\section{Pengaruh Biaya Kesejahteraan Pegawai terhadap Kinerja Sosial Perusahaan}

Berdasarkan hasil perhitungan statistik bahwa nilai koefisien determinasi $\left(\mathrm{R}^{2}\right)$ sebesar 0.349 , menunjukan bahwa $34.9 \%$ variasi dalam $\mathrm{Y}$ kinerja sosial dapat dijelaskan oleh $\mathrm{X}_{2.13}$ biaya bonus dan $\mathrm{X}_{2.14}$ biaya tantiem, sisanya sebesar $65.1 \%$ dijelaskan oleh variabel lain yang tidak dimasukkan dalam model persamaan ini. Simpulan ini selanjutnya diuji secara parsial melalui uji $\mathrm{t}, \alpha=5 \%$ uji 2 arah menunjukan $\mathrm{t}_{\text {hitung }}$ sebesar 2.140 dan 2.630 lebih besar dari $\mathrm{t}_{(0.1 ; 14)}=2.101$ kemudian secara serempak melalui uji $\mathrm{F}, \alpha$ $=5 \%$. Hasil perhitungan menunjukan $\mathrm{F}_{\text {hitung }}$ sebesar 4.561 dengan demikian $\mathrm{F}_{\text {hitung }}>\mathrm{F}_{\text {tabel }}$ (3.52) maka $\mathrm{H}_{0}$ ditolak. Artinya, bonus dan tantiem yang diberikan para pegawai baik secara parsial maupun serempak berpengaruh secara nyata terhadap kinerja sosial perusahaan. 
Hasil penelitian menggambarkan bahwa biaya kesejahteraan pegawai yang paling dominan akan mempengaruhi kinerja sosial perusahaan adalah biaya bonus dan tantiem yang diberikan kepad pegawai maka akan meningkatkan kinerja sosial perusahaan. Hal tersebut dikarenakan, dengan adanya pemberian bonus dan tantiem sebagai insentif kepada para pegawai akan meningkatkan produktifitas pegawai sehingga akan berimplikasi terhadap membaiknya citra perusahaan di masyarakat.

Hasil penelitian ini sesuai pula dengan teori kepuasan dari Maslow (1943); dan Herzberg (1959); Mc Clelland (1961). Asumsi dasar teori itu ialah bahwa individu memilih perilaku pribadi atas dasar: Pengharapan bahwa perilaku itu akan menghasilkan suatu keluaran tertentu; Jumlah valensinya, yakni manfaat pribadi atau imbalan yang diperoleh dari hasilnya. Hasil penelitian yang penulis lakukan mendukung teori yang dikemukakan ketiga ahli tersebut yang menyatakan bahwa biaya kesejahteraan pegawai berpengaruh secara signifikan terhadap kinerja sosial perusahaan terbuka di Indonesia.

\section{Pengaruh biaya Masyarakat Sekitar Perusahaan terhadap Kinerja Sosial Perusahaan}

Berdasarkan hasil perhitungan statistik nilai koefisien determinasi $\left(\mathrm{R}^{2}\right)$ sebesar 0.277 , menunjukkan bahwa $27,7 \%$ variasi dalam Y kinerja sosial dapat dijelaskan oleh $\mathrm{X}_{3.2}$ biaya air bersih, sisanya sebesar $72,3 \%$ dijelaskan dalam variabel lain yang tidak dimasukkan dalam model persamaan ini. Simpulan tersebut selanjutnya diuji secara parsial melalui uji $\mathrm{t}, \infty=5 \%$ uji 2 arah menunjukkan $\mathrm{t}_{\text {hitungi }}$ sebesar 2,623 lebih besar dari $\mathrm{t}_{(0,1 ; 14)}=2,093$ kemudian diuji secara serempak melalui uji $\mathrm{F}, \infty=5 \%$. Hasil perhitungan menunjukkan $\mathrm{F}_{\text {hitung }}$ sebesar 6,879 dengan demikian $\mathrm{F}_{\text {hitung }}>\mathrm{F}_{\text {tabel }}(4,38)$ maka $\mathrm{H}_{0}$ ditolak. Hal itu menunjukkan bahwa biaya air bersih yang diberikan perusahaan kepada masyarakat, baik secara parsial maupun serempak berpengaruh secara nyata terhadap kinerja sosial perusahaan.

Berdasarkan hasil uji statistik tersebut menunjukkan biaya masyarakat sekitar perusahaan yang paling dominan berpengaruh terhadap kinerja sosial perusahaan adalah biaya air bersih. Hal itu berarti semakin besar biaya air bersih yang diberikan kepada masyarakat sekitar perusahaan akan meningkatkan kinerja sosial perusahaan. Hal tersebut karena dengan adanya pemberian air bersih yang diberikan kepada masyarakat sekitar perusahaan akan memberikan ketenangan kepada masyarakat sekitar perusahaan dan merasa terbantu sebagian biaya hidupnya melalui kebutuhan pokok berupa air terutama untuk air sudah tercemar dengan kehadiran perusahaan ini. Hasil penelitian ini sesuai dengan pendapat yang dikemukakan Marbun (1991) yang mengatakan bahwa apabila perusahaan tidak memperhatikan seluruh faktor yang mengelilinginya, mulai dari karyawan, konsumen, lingkungan, dan sumber daya alam satu kesatuan yang saling mendukung sebagai suatu sistem maka akhirnya akan mengakhiri eksistensi perusahaan itu sendiri. 


\section{Pengaruh Biaya Pemantauan Produksi terhadap Kinerja Sosial Perusahaan}

Berdasarkan hasil perhitungan statistik nilai koefisien determinasi $\left(\mathrm{R}^{2}\right)$ sebesar 0,185 menunjukkan bahwa $18,5 \%$ variasi dalam Y kinerja sosial dapat \% dijelaskan oleh variabel lain yang tidak dimasukkan dalam model persamaan ini. Simpulan tersebut diuji melalui uji $\mathrm{t}, \infty=\%$ uji 2 arah menunjukan $\mathrm{t}_{\text {hitung }}$ sebesar 2.025 lebih kecil dari $\mathrm{t}_{(0.05 ; 14)}=$ 2.093, kemudian secara serempak melalui uji $\mathrm{F}, \infty=5 \%$. Hasil perhitungan menunjukan $\mathrm{F}_{\text {hitung }}$ sebesar 4.099, dengan demikian $\mathrm{F}_{\text {hitung }}>\mathrm{F}_{\text {tabel }}$ (4.38) maka $\mathrm{H}_{0}$ diterima. Artinya, biaya layanan masyarakat, baik secara parsial maupun serempak tidak berpengaruh secara nyata terhadap kinerja sosial perusahaan.

Hasil penelitian menggambarkan bahwa biaya pemantauan produksi yang paling dominan berpengaruh terhadap kinerja sosial perusahaan adalah biaya iklan layanan masyarakat, walupun tidak signifikan. Hal itu berarti semakin besar biaya iklan layanan masyarakat yang dikeluarkan perusahaan akan meningkatkan kinerja sosial perusahaan. Hal tersebut penting dikarenakan konsumen juga perlu mendapatkan perlindungan dari prsodusen atas prosuk yang dikonsumsinya, seperti peringatan kepada para pemakai rokok yang ditulis pada sampul rokok yang menyatakan bahwa merokok menggangu kesehatan atau dengan mencantumkan spesifikasi dari prosuk yang dihasilkan. Ada juga label halal untuk produk makanan dan minuman bagi umat Islam. Tidak signifikannya biaya iklan layanan masyarakat terhadap kinerja sosial, mungkin juga diakibatkan oleh tingkat kepedulian masyarakat di Indonesia sendiri belum mencapai pada taraf apakah perusahaan mempunyai atensi yang tinggi atau tidak yang berkaitan dengan iklan layanan masyarakat tersebut. Bahkan, dari pihak konsumen sendiri belum memiliki pemahaman yang memadai yang berkatan dengan eko label ini. Hasil penelitian ini sesuai pula dengan pendapat Heard dan Bolce (1981) bahwa sebelumnya masyarakat memandang perusahaan hanya bertanggung jawab dalam penyediaan barang dan jasa, lapangan kerja, dan meningkatkan kesejahteraan masyarakat. Masyarakat tidak lagi membatasi tuntutannya atas terpenuhinya barang, jasa, dan kesempatan kerja, tetapi menuntut para pengusaha untuk memperimbangkan dan mempertanggungjawabkan persoalan lingkungan dan kemanusiaan dalam aktivitas usahanya. Masyarakat menuntut persoalan itu dijadikan sebagai tanggung jawab perusahaan (masalah internal), bukan tangging jawab masyarakat (masalah eksternal) sehingga harus dipertimbangkan dalam setiap pengambilan keputusan.

\section{Pengaruh Biaya Sosial terhadap Kinerja Sosial Perusahaan}

Berdasarkan perhitungan statistik bahwa variabel biaya sosial yang paling dominan berpengaruh terhadap kinerja sosial perusahaan adalah biaya gaji dan upah bagian lingkungan sebesar 0,58446 , biaya air bersih untuk masyarakat sekitar perusahaan sebesar 0,533483 , biaya bonus pegawai sebesar 0,393087 , biaya tantiem untuk pegawai sebesar 0,375627, dan biaya layanan masyarakat sebesar 0,349567. Hasil perhitungan itu menggambarkan bahwa pengaruh biaya sosial yang paling dominan terhadap kinerja sosial perusahaan di Indonesia ada lima variabel, yaitu biaya gaji dan upah, biaya air 
bersih, biaya bonus, biaya tantiem, dan biaya iklan layanan masyarakat. Hal itu berarti semakin besar biaya gaji dan upah, biaya air bersih, biaya bonus, biaya tantiem, biaya iklan layanan akan meningkatkan kinerja sosial perusahaan.

Hasil penelitian ini sesuai pula dengan penelitian Ernst \&Ernst (1971). Walaupun sedikit agak berbeda mengenai variabel yang dominannya, seperti halnya hasil penelitian Arpan dan Radebaugh (1981) mengatakan bahwa perusahaan di Prancis diharuskan membuat neraca sosial yang ditujukan untuk para pegawai dan manajemen yang dibuat setiap tahun. Neraca sosial tersebut mengkonfirmasikan mengenai: pegawai, gaji, kesehatan dan perlindungan keamanan, kondisi lain dalam bekerja, training pegawai, Hubungan industri, kondisi lain yang menyangkut kehidupan, termasuk perumahan dan transportasi para pegawai perusahaan.

\section{Pengaruh Kinerja Sosial terhadap Kinerja Keuangan Perusahaan}

Berdasarkan hasil perhitungan statistik dengan nilai koefisien determinasi $\left(\mathrm{R}^{2}\right)$ sebesar 0.091, menunjukkan bahwa 9,1\% variasi dalam $\mathrm{Z}$ kinerja keuangan dapat diterangkan dalam variasi Y kinerja sosial, sisanya sebesar 90,9\% dijelaskan oleh variabel lain yang tidak dimasukkan dalam model persamaan ini. Simpulan tersebut selanjutnya diuji dengan uji $t, \infty=5 \%$ uji 2 arah menunjukkan $t_{\text {hitung }}$ sebesar $-1,346$ lebih kecil dari $\mathrm{t}_{(0,1,19)}=2,093$. Hal itu menunjukkan bahwa kinerja sosial secara parsial tidak berpengaruh secara nyata terhadap kinerja keuangan. Selanjutnya, secara serempak melalui uji $\mathrm{F}, \infty=$ $5 \%$. Hasil perhitungan menunjukkan $\mathrm{F}_{\text {hitung }}$ sebesar 1,8111, dengan demikian $\mathrm{F}_{\text {hitung }}<\mathrm{F}_{\text {tabel }}$ $(4,38)$ maka $\mathrm{H}_{0}$ tolak. Artinya, variabel kinerja sosial secara serempak tidak berpengaruh secara nyata terhadap kinerja keuangan.

Hasil penelitian menggambarkan bahwa pengaruh kinerja sosial terhadap kinerja keuangan perusahaan tidak ada. Hal itu disebabkan tingkat kepedulian masyarakat secara umum belum naik. Artinya, sekali pun para pengusaha sudah melakukan kepedulian terhadap lingkungannya tetapi bilamana masyarakat konsumen sebagai pemakai produk perusahaan tidak memiliki kepedulian terhadap masalah lingkungan maka usaha tersebut tidak akan mempunyai dampak yang positif terhadap kinerja keuangan para emiten. Alasan tersebut dapat ditunjukkan dari tingkat kesadaran ataupun pemahaman masyarakat untuk membedakan mana perusahaan yang peduli terhadap lingkungan dengan yang tidak masih sedikit. Kepedulian para konsumen di Indonesia berkaitan pula dengan tingkat daya beli masyarakat atau pendapatan yang pada umumnya masih rendah. Artinya, para konsumen masih berpikir pada taraf yang penting terjangkau kebutuhannya, belum memikirkan apakah produk tersebut ramah lingkungan atau tidak. Hal tersebut disebabkan oleh tingkat pendapatan per kapita Nasional yang masih rendah dibandingkan dengan negara lain sehingga hal itu dapat berimplikasi terhadap tingkat kepedulian masyarakat terhadap masalah lingkungan. Hasil penelitian ini sesuai pula dengan hasil penelitian Yamagami \& Kokubu (1991) yang menyatakan di Jepang pelaksanaan pengungkapan tanggung jawab sosial perusahaan berjalan secara lambat dibandingkan di USA dan Negara Eropa (Ernst \& Ernst, 1978; Dierkers, 1980; Rey, 1980; Gray dkk., 
1987;). Hasil penelitian Luynn (1992) di Hongkong pengungkapan tanggung jawab sosial lebih rendah dibandingkan di Malaysia dan Singapura (lihat Andrews dkk., 1989).

\section{DAFTAR PUSTAKA}

Adams, Carol A., Wan-Ying Hill, and Clare B. Robert. 1997. "Corporate Social Reporting Practices in Western Europe: Legitimating Corporate Behaviour?" Working Paper \# 97/3, Glasgow: Department of Accounting \& Finance, University of Glasgow, England.

Andrew, B.H., F.A.Gaul, J.E. Guthrie, and H.Y. Teoh. 1989. "A Note on Corporate Social Disclosure Practises in Developing Countries: The Case of Malaysia and Singapore.” British Accounting Review, No.21,pp.371-376.

Choi, Jong-Seo. 1998. "An Investigation of Initial Voluntary Environmental Disclosures Made in Korean Semi-Annual Financial Report." paper presented on the AsiaPacific Interdisciplinary Research on Accounting (APIRA) Symposium, Osaka City University, August 4-6.

Global Reporting Initiative (GRI)-Coalition for Environmentally Responsible Economies (CERES). 1999. Sustainability Reporting Guidelines. Boston:CERES and GRI Sekretariat.

Gray, Rob, Reza Kouhy, and Simon Lavers. 1995a. "Constructing A Research Database of Social and Environmental Reporting", by UK Companies, Accounting, Auditing \& Accountability Journal, Vol. 8 No.5, pp. 78-101.

Gray, Rob, Reza Kouhy, and Simon Lavers. 1995b. "Corporate Social and Environmental Reporting; A Review of the Literature and A Longitudinal Study of UK Disclosure." Accounting, Auditing \& Accountability Journal, Vol. 8 No.2, pp. 47-77. 